\title{
PARTICIPAÇÃO SOCIAL, CULTURA POLÍTICA E INDICADORES DE ASSOCIATIVISMO: OS DIRIGENTES DE ENTIDADES SOCIAIS
}

Celene Tonella

\begin{abstract}
Resumo
A idéia central da presente discussão é a de que a luta pela construção democrática localiza-se no próprio espaço da sociedade civil, e não apenas no espaço do Estado. Entende-se que práticas associativas dinamizam a vida democrática, são espaços de socialização política e cívica, são canais de interlocução entre a sociedade e o Estado, além de serem espaço de formulação/questionamento de políticas públicas. O artigo tem como tema a cultura política e o associativismo no âmbito local. Interessa explorar a emergência de uma cultura cívica e política favorável à afirmação da cidadania e à construção de práticas democráticas na área da Região Metropolitana de Maringá - Paraná. O comportamento político, traduzido em termos da cultura política dos dirigentes de associações da sociedade civil, permitirá medir as relações e atitudes em relação ao sistema político.
\end{abstract}

Palavras-chave: Participação Social; Associativismo; Cultura Política; Assistência; Entidades Sociais; Democracia.

\begin{abstract}
The central idea of the present discussion is that, the struggle for constructing democracy is located within the civil society, not just within the State. It is understood that entities in associative practices make democratic life more dynamic, once such entities are spaces where there is political and civic socialization; they are open communication channels between the society and the State and are also, spaces for formulating and questioning public politics and policies. The present paper has as main focus the political culture and the associativism in the local extent. It aims at exploring the emergence of a civic and political culture, favorable to the establishment of citizenship, and to the construction of democratic practices in the Metropolitan Area of Maringá Paraná. The political behavior, translated in terms of political culture of leaders of civil society associations, will enable to measure the relations and attitudes concerning the political system.
\end{abstract}

Key-words: Social Engagement; Associativism; Political Culture; Assistance; Social Entities; Democracy.

\section{Introdução}

O público-alvo da pesquisa é composto pelos chamados informantes qualificados, e foram entrevistados representantes das diretorias das entidades cadastradas nos conselhos de Assistência Social dos 3 municípios que compõem a chamada mancha urbana da Região 
Metropolitana de Maringá (Maringá, Sarandi e Paiçandu ${ }^{1}$ ), em um universo de 100 entidades, sendo entrevistados 87 dirigentes. A composição das entidades varia das mais tradicionais (a maioria) que atuam na área da assistência como asilos, creches, Apaes (Associações de Pais e Amigos de Excepcionais), até aquelas de novo perfil, como Organizações Não-Governamentais (ONGs) ligadas ao meio-ambiente, entidades culturais, de mulheres e indígenas. Os dirigentes são agentes políticos, pois estão em contato permanente com a elaboração/proposição de políticas públicas. Pressupõe-se que tenham um poder de influência maior que o cidadão comum, que estejam mais entrosados na sociedade local e tenham capacidade de acelerar ou retardar processos de participação, já que exercem também uma função educativa em relação aos componentes de suas associações e mesmo de toda a sociedade local. E, finalmente, têm potencial para tencionar as estruturas de dominação existentes.

O tema da participação e da organização da sociedade civil esbarra em condicionantes estruturais que emperram o acesso aos direitos sociais. Ainda que se considere que a democracia política esteja instalada em seus formatos institucionais de forma satisfatória, a exclusão econômica no Brasil atinge patamares de tal gravidade que nos permitem apontar, senão a total exclusão, ao menos obstáculos severos à participação de parcelas significativas da população na vida política. Resende e Tafner (2005) trabalham com a idéia do custo da participação. A Constituição Federal garante a todos os indivíduos e grupos sociais o direito de organização e reivindicação, mas, na prática, organizar, freqüentar reuniões, reivindicar e encaminhar demandas representa um volume não desprezível de energias e tempo e, muitas vezes, tempo roubado do trabalho e da convivência com familiares. Os autores dão o exemplo dos projetos de iniciativa popular, plebiscito ou referendo para interferir no processo legislativo não custa a mesma coisa para grupos de rendas diferenciadas. Um outro exemplo é quando, em alguns espaços, surge o polêmico tema da remuneração de

1 População: Maringá - 325.968 habitantes; Sarandi - 79.686 habitantes e Paiçandu 34.640 habitantes. Fonte: IBGE. Disponível em:<http://www.ibge.gov.br>. Acesso em 12 dez. 2007. 
conselheiros representantes de entidades da sociedade civil para garantir participação mais eficaz. Apesar das dificuldades estruturais, o campo associativo tem crescido enormemente no Brasil nas duas últimas décadas. Verifica-se a proliferação de ONGs, entidades representativas de segmentos específicos, conselhos municipais, estaduais, orçamento participativo e fóruns.

É preciso reconhecer que, se existem condicionantes que limitam os processos participativos, temos também forças que atuam a favor da participação. Como destacam vários autores, entre eles Held (1987) e Pateman (1992), a participação é um processo de aprendizado. É como se houvesse um círculo virtuoso, quanto mais o indivíduo participa, mais se sente compelido a participar. É nesse sentido que apontam pesquisas, como as realizadas por Krischke (2004) sobre o aprendizado da democracia e Fedozzi (1997) sobre os processos de desenvolvimento moral dos indivíduos. Os indivíduos inseridos em instâncias participativas, como, por exemplo, o Orçamento Participativo, tendem a ampliar sua prática envolvendo-se em atividades correlatas.

Explicar o papel dos agentes cujas atuações são tencionadas por estruturas de poder arcaicas, centradas ainda no clientelismo e na troca de favores, e por novas estruturas, nas quais o sujeito é chamado a participar em nome da cidadania, remete ao campo de estudos da cultura política, entendida como a forma pela qual as atitudes dos cidadãos são estruturadas em relação ao sistema político. O campo foi inaugurado com os estudos de Almond e Verba, de 1963 e o conceito foi elaborado a partir de uma concepção normativa de sociedade, com base nas realidades norte-americana e inglesa. O propósito era mostrar que a estabilidade da democracia em um país dependia não só de suas instituições democráticas, mas das atitudes da população. Na obra original, os autores apontam que Estados Unidos e Grã-Bretanha eram mais estáveis e sólidos graças à solidez da cultura política e, por outro lado, os outros países estudados, principalmente Alemanha e Itália, resultaram em democracias frágeis devido à fragilidade da cultura política. Os pesquisadores não levaram em conta, neste primeiro trabalho, os modelos de democracia, níveis de desenvolvimento ou 
outros indicadores. O trabalho tem recebido críticas ao longo dos anos, mas continua sendo uma referência necessária, se entendida como ponto de partida para novas reflexões que mesclem ao conceito original as experiências históricas das realidades estudadas. Concordamos com Castro $(\mathrm{s} / \mathrm{d})$ quando afirma que:

[...]se as proposições de Almond e Verba não conseguiram dar conta das inúmeras realidades, inauguraram uma forma de analisar e explicar a política. A partir daí, a evolução do debate sobre o tema, bem como a possibilidade e a disseminação de novos estudos empíricos, permitiram que hoje se possa falar em uma Cultura Política que vai além da classificação proposta em 1963 (CASTRO, s/d, p.2).

A partir de um contexto em que se apresenta, de um lado, ampla possibilidade de participação e, de outro, a persistência de consideráveis desigualdades de acesso a bens materiais, culturais e políticos, explicar a visão de mundo de sujeitos diretamente envolvidos com práticas coletivas, por meio da aferição da cultura política, pode vir a ser uma contribuição importante para se entender as condições necessárias para a potencialização das transformações em curso.

Some-se à discussão o conceito de nova cultura política, desenvolvido por Clark e Hoffmann-Martinot (1998) e que chega até nós pelos textos de Cabral e Silva (2006). Os autores citados apontam que está em andamento, notadamente nos países desenvolvidos, a institucionalização do individualismo exacerbado em detrimento da comunidade. Os indivíduos que habitam grandes metrópoles tenderiam a buscar uma melhor qualidade de vida para si e para sua família, mas não estariam dispostos a estender os esforços de forma a lutar por direitos coletivos e cidadania. As características centrais do novo comportamento seriam justamente o crescimento da preocupação com temas sociais e com uma participação cidadã somadas a um menor envolvimento com entidades e práticas coletivas. Estaria se configurando nas metrópoles latinas o mesmo tipo de comportamento? Apresenta-se aqui um viés de análise a ser melhor explorado. 
No caso do segmento escolhido como alvo da presente pesquisa, são inerentes as preocupações com temas sociais. No entanto, aqueles que lidam com as políticas sociais têm acompanhado e sido chamados a dar respostas às mudanças profundas pelas quais tem passado o setor. A Constituição de 88 e seu desdobramento na LOAS - Lei Orgânica da Assistência Social (Lei 8742/93) - foi marco fundamental nesse contexto de mudanças, pois deslocou a assistência do campo da filantropia para o da política pública. Esse deslocamento colocou novas exigências para um conjunto de entidades que, atuando sob a lógica da certificação/isenção, desenvolvia trabalhos nas áreas da saúde, educação, assistência etc. As novas diretrizes demandaram uma maior transparência e qualidade dos serviços prestados por elas, que deveriam obedecer, assim, critérios mais públicos de atuação estabelecidos pelos conselhos gestores, organizados nas diferentes esferas de governo.

Como aconteceu também em outras áreas, as mudanças que a Constituição de 88 apontou para a assistência social provocou impactos no sentido de contemplar demandas do mercado. Conforme apontaram vários analistas ${ }^{2}$, informadas por aquelas reformas, as iniciativas operadas nessa área pulverizam as ações e passaram ao largo da LOAS, o que representou uma contra marcha no movimento de criação efetiva de um sistema público de seguridade no país. As entidades sociais foram incentivadas a intensificar sua atuação social como contrapartida do projeto que estava em curso e que previa a diminuição das responsabilidades sociais do Estado. Diante do novo quadro, o restrito certificado de entidade beneficente também não foi mais considerado suficiente, pois para ter espaço nesse cenário, tais entidades teriam que se profissionalizar, assumir a lógica da elaboração de projetos - que se mostrassem viáveis e eficazes - e se enquadrar nas novas legislações criadas para regular as parcerias Estado/sociedade civil ${ }^{3}$.

O Sistema Nacional de Assistência Social (Suas) foi resultado das mobilizações ocorridas a partir das diretrizes da Conferência Nacional de

\footnotetext{
${ }^{2}$ Ver, dentre outros, Raichelis (1998).

${ }^{3}$ Como por exemplo, a Lei das OSCIPs - Organizações da Sociedade Civil de Interesse Público, de 1998.
} 
Assistência Social de 2003 e da mudança de governo, no plano federal, em 2002. O Suas dotou de novo estatuto as entidades assistenciais. Elas, agora, passam a ser consideradas não apenas executoras de ações e programas sociais, mas integrantes ativas da rede gestora e executora da política de assistência. Para serem assim consideradas, devem desenvolver as ações que são previstas por aquela política, de forma continuada e sistematicamente avaliada. Devem, portanto, dar contornos mais definidos à sua atuação, atendendo às resoluções específicas que têm por objetivo diferenciá-las de outras entidades assistenciais e beneficentes. A Resolução 191, do Ministério do Desenvolvimento Social e do Conselho Nacional de Assistência Social, de 2005, estabelece no seu texto que as entidades de assistência social devem apresentar em seu relatório de atividades, seus objetivos, sua natureza, missão e público conforme delineado pela LOAS, pela PNAS (Plano Nacional de Assistência Social) e suas normas operacionais (BRASIL, 2005).

Não foram poucas, portanto, as mudanças pelas quais as - agora denominadas pelo novo marco legal da PNAS - entidades de assistência social passaram desde os anos 1990 . Por isso mesmo e pela importância que elas adquirem hoje no âmbito da área em que atuam, empreendemos um esforço de compreender algumas das dimensões constitutivas da sua prática (TONELLA e ALMEIDA, 2007).

Diante das demandas que emergiram das mudanças, as práticas e os discursos tradicionais das denominadas entidades assistenciais, fundados fortemente nas obrigações religiosas e caritativas, foram confrontados com a linguagem da cidadania e da participação num contexto em que essa própria linguagem estava sendo mobilizada tanto em nome da universalização do acesso aos serviços públicos e da democratização das suas formas de gestão, quanto em nome da necessidade de diminuir as responsabilidades sociais do Estado, transferindo-as para organizações sociais eficazes e profissionalizadas. Esse segmento, que remonta aos primeiros formatos associativos existentes no Brasil, experimenta, assim, o desafio de conferir novos significados ao seu papel num contexto em que as inflexões ocorridas 
nas últimas décadas em termos de paradigmas e modelos de intervenção social, ainda estão sob disputas (TONELLA e ALMEIDA, 2007).

\section{Resultados da pesquisa}

\section{Indicadores sócio-demográficos}

As faixas etárias dos dirigentes das entidades sociais predominantes são as de $40-49$ anos (31\%) e 50 anos ou mais $(48,3 \%)$. Essas entidades são fortemente marcadas pela presença feminina, no entanto, como acontece em outros contextos, nos cargos de lideranças predominam os homens (no nosso caso, de todos os entrevistados, 56,3\% são homens).

A escolaridade dessas lideranças apresentou-se acima da média da população, sendo o ensino médio completo ou incompleto indicado por $25,3 \%$ dos entrevistados e o ensino superior completo ou incompleto, por $46 \%$.

Quanto à cor, 80,5\% declararam-se brancos, 16\% pardos e 3,4\% amarelos. Chama a atenção o fato de que em Sarandi e Paiçandu existam mais lideranças pardas. Para as duas cidades, $66,7 \%$ são brancos e 33,3\% são pardos, enquanto que em Maringá são 85,7\% de brancos e apenas $9,5 \%$ de pardos. Nenhum dirigente definiu-se como negro e poucos são amarelos, em uma região onde a imigração japonesa tem presença marcante.

No questionário geral, chama a atenção o significativo índice daqueles que trabalham em instituições sem fins lucrativos $(27,6 \%)$. Tanto em Maringá $(30,1 \%)$ como em Sarandi $(22,2 \%)$, esse enquadramento está bastante presente. Em Paiçandu, entretanto, esse não é o enquadramento mais presente (compõe apenas 16,7\%). Ou seja, as lideranças em Paiçandu são as que estão menos liberadas para o trabalho em organizações sociais. 
Tabela 1 - Renda Individual Mensal (em salários mínimos) \%

\begin{tabular}{|c|c|}
\hline Renda & $\%$ \\
\hline 1. sem renda & 8,1 \\
\hline 2. de 1 a 3 & 28,7 \\
\hline 3. mais de 3 até 5 & 21,8 \\
\hline 4. mais de 5 até 10 & 17,2 \\
\hline 5. mais de 10 até 15 & 12,6 \\
\hline 6. mais de 15 & 1,1 \\
\hline 7. mais de 20 & 5,7 \\
\hline 8. $\mathrm{nr}$ & 4,6 \\
\hline total geral & 100 \\
\hline
\end{tabular}

Fonte: Observatório das Metrópoles Núcleo Região Metropolitana de Maringá4 .

Tabela 2 - Posição na Escala social comparativa Maringá, Paiçandu e Sarandi (\%)

\begin{tabular}{l|c|c|c|c}
\hline Escala & Geral & Maringá & Paiçandu & Sarandi \\
\hline $1 *$ & 5,7 & 3,2 & 16,7 & 11,1 \\
\hline 2 & 10,3 & 12,7 & 0,0 & 5,6 \\
\hline 3 & 51,7 & 54,0 & 50,0 & 44,4 \\
\hline 4 & 20,7 & 20,6 & 33,3 & 16,7 \\
\hline 5 & 11,5 & 9,5 & 0,00 & 22,2 \\
\hline \multicolumn{4}{r}{ * ra escala, 1 representa o topo e 5, a base. }
\end{tabular}

Fonte: Observatório das Metrópoles Núcleo Região Metropolitana de Maringá.

Em relação à renda individual, as três cidades apresentam diferenças que devem ser mencionadas. Em Maringá, percebe-se uma maior heterogeneidade quanto à distribuição entre os níveis de renda, mas a concentração está entre aqueles que ganham de 3 a 5 salários $(22,2 \%)$ e entre 5 e 10 (20,6\%). Assim, pode-se dizer que em Maringá predominam as lideranças compostas pelas classes médias, com alguma distribuição entre a base e o pico da pirâmide social. Os dados desagregados indicam o seguinte: em Sarandi, parece estar representada a pirâmide social brasileira, com concentração na base: $61,1 \%$ ganham de 1 a 3 salários, enquanto que 5,6\% ganham mais de 20 salários. Em Paiçandu, diferentemente, a concentração é toda na base da pirâmide.

Para Maringá, a identificação com a classe social corresponde aos dados sobre renda, já que a maioria se diz pertencer às classes 3 e 4 . Já em Sarandi, há um contraste entre os dados sobre renda e a percepção

${ }^{4}$ Os dados do Observatório das Metrópoles - Região Metropolitana de Maringá são disponibilizados mediante solicitação no link Solicitação de dados, disponível no site do observatório <http://www.cch.uem.br/observatorio/index.php>. 
quanto à classe a que pertencem. Enquanto os dados de renda revelam a existência de uma concentração na base da pirâmide, os que se referem à identificação de classe se concentram nos níveis médios da pirâmide. Em Paiçandu, o contraste também se verifica, pois enquanto a concentração dos dados de renda, até mesmo mais do que em Sarandi, é na base da pirâmide, os dados sobre percepção indicam que as lideranças se consideram pertencentes às classes 3 e 4.

É possível compreender esses dados se levamos em conta que Sarandi e Paiçandu concentram a pobreza existente na mancha urbana em questão. Desse modo, a percepção quanto ao pertencimento à classe social nessas duas cidades é construída de maneira relacional ao seu entorno mais imediato. De fato, as lideranças das entidades, nesses casos, pertencem às camadas economicamente mais privilegiadas da sua comunidade.

Tabela 3 - Religião (\%)

\begin{tabular}{l|c}
\hline \multicolumn{1}{c|}{ Religião } & $\%$ \\
\hline 01. Evangélico pentecostal & 12,6 \\
\hline 02. Evangélico não pentecostal & 9,2 \\
\hline $\begin{array}{l}\text { 03. Umbanda, candomblé ou outra de origem } \\
\text { africana }\end{array}$ & 0,0 \\
\hline 04. Espírita & 6,9 \\
\hline 05. Católica praticante & 51,7 \\
\hline 06. Católica não praticante & 16,0 \\
\hline 07. Judaica & 0,0 \\
\hline 08. Muçulmana & 0,0 \\
\hline 09. Agnóstico (descrente) & 1,1 \\
\hline 10. Não tem religião, mas acredita em deus & 0,0 \\
\hline 11. Não crê em deus (ateu) & 0,0 \\
\hline 12. NS/NR & 0,0 \\
\hline 13. Outra religião & 2,3 \\
\hline \multicolumn{1}{c}{ Total } & 100 \\
\hline
\end{tabular}

Fonte: Observatório das Metrópoles Núcleo Região Metropolitana de Maringá.

O intenso envolvimento dos entrevistados com a igreja católica se confirma diante do perfil religioso: 51,7\% afirmaram-se católicos praticantes e $16,1 \%$ católicos não praticantes. Protestantes pentecostais e não pentecostais somaram $21,8 \%$; enquanto os espíritas somaram 6,9\%. Como Doimo (2004, p. 51-2) afirma: 


\begin{abstract}
o incentivo à formação de grupos e congregações de leigos visando à promoção de assistência social, filantropia, reivindicações coletivas, obras sociais ou cooperativas independentes, é claramente perceptível no estudo do associativismo religioso na cidade de São Paulo desde o período oligárquico até os dias atuais.
\end{abstract}

A vinculação de parte dos entrevistados a igrejas protestantes pentecostais e não pentecostais, bem como a centros espíritas, está em consonância com mudanças recentes ocorridas no perfil de religiosidade dos brasileiros. Comparando as três cidades, chama a atenção, entretanto, o fato de que em Maringá há uma heterogeneidade maior em relação à vinculação religiosa. Nessa cidade, aparecem os espíritas e os agnósticos; em Sarandi e Paiçandu aparecem apenas católicos e protestantes. Essa heterogeneidade quanto à religião, ainda que pequena, reflete o caráter mais metropolitano de Maringá em comparação com as duas outras cidades. Verificando a lista das entidades cadastradas nos conselhos de assistência dos três municípios, constata-se que o perfil do associativismo presente em Maringá é significativamente mais heterogêneo (ainda que bastante marcado pela origem religiosa), incluindo organizações típicas dos anos 1990, como, por exemplo, aquelas de defesa dos direitos dos povos indígenas, das mulheres e dos portadores do HIV.

Assim, em perspectiva comparada, é de se presumir que as lideranças de Maringá estejam mais suscetíveis ao "efeito metrópole", apresentando nuances nas suas percepções em relação à cidadania e às suas formas de exercício.

2. Indicadores sobre atitudes $\mathrm{e}$ percepções em relação ao sistema político, a formas de exercício da cidadania e à prédisposição para a ação política

Ao se tratar da implantação/construção de um modelo de democracia, surge naturalmente a questão da conquista da cidadania. Ainda que os dois conceitos não se confundam e tenham naturezas diferentes, em casos como o de luta pelo retorno à normalidade 
democrática nos contextos das ditaduras brasileira e latino-americanas, o discurso político esteve impregnado da idéia de cidadania e ela se tornou uma bandeira de luta por direitos.

Compreende-se a cidadania como um método de inclusão em suas múltiplas dimensões. A base das reflexões está na obra clássica de T. H. Marshall, de $1949^{5}$, e, a partir dela, tornou-se costume desdobrar a cidadania em direitos civis, políticos e sociais. Essa seqüência corresponde à experiência inglesa e, como bem aponta Carvalho (2004), no Brasil não se aplica o modelo inglês, ele serve apenas para comparação por contraste. As inúmeras tentativas de ampliação das conquistas sociais resultaram em derrotas políticas para os protagonistas da ação. Um exemplo balizador, que serve para demonstrar a inversão da seqüência, é o período varguista, em que importantes direitos sociais foram conquistados pelos trabalhadores em um cenário de total subtração dos direitos políticos. Um outro momento importante de luta popular pela restituição dos direitos políticos ocorreu durante a ditadura militar, marcada pela intensa mobilização da sociedade fora dos espaços tradicionais, como as organizações de bairro, as comunidades eclesiais de base, o movimento de mulheres, entre muitos outros.

As décadas de 1970 e 1980, que, para nós, foram de resistência à ditadura militar, registraram inúmeras transformações ocorridas em nível mundial, vinculadas centralmente à crise do Estado de Bem Estar e à falência do socialismo real. Em termos teóricos, ocorre a retomada do conceito de sociedade civil, estreitamente vinculado às discussões dos movimentos sociais ${ }^{6}$.

No caso em tela, trabalha-se com membros de diretorias de associações, que em muitos casos, são também membros de Conselhos Gestores como os da Assistência Social, da Criança e do Adolescente, Anti-Drogas e dos Idosos. Cremos que a construção da democracia passa também pelo fortalecimento dessas instâncias. Os Conselhos

\footnotetext{
${ }^{5}$ Utilizamos a edição brasileira, de 1967.

${ }^{6}$ Quanto à discussão sobre a redescoberta do conceito de sociedade civil, ver Costa (1994).
} 
Gestores de Políticas Públicas apareceram como novos espaços de articulação de inúmeras demandas. A partir de legislação específica, formatada por área, nos primeiros anos da década de 1990, viabilizouse a participação dos setores sociais interessados na formulação das diretrizes de políticas e no controle mais efetivo sobre as ações estatais ${ }^{7}$.

Como já apontamos anteriormente, representantes da sociedade civil ou têm sido chamados a participar do processo decisório pelos governos democráticos ou abrem espaços de participação, por meio da organização e articulação em entidades e movimentos sociais.

A intenção dos dados abaixo é apontar o acúmulo das experiências reunidas ao longo dos anos e mensurar itens como exercício da cidadania, avaliação das instituições, perfil associativo, importância de participar da vida política e compreensão da política.

\footnotetext{
${ }^{7}$ Nos últimos anos, a temática dos Conselhos e do Orçamento Participativo apareceu com bastante intensidade em diversos fóruns como os congressos da Sociedade Brasileira de Sociologia (2003), e os encontros de Associação Brasileira de Ciência Política, entre outros. Além disso, a bibliografia com análises de casos específicos é extensa. Para o orçamento participativo, citamos: Ribeiro e Grazia (2003), Genro e Souza (1997), Avritzer (2002). Para os Conselhos Gestores: Gohn (1990), Tatagiba (2002), Perissinoto (2002), Tonella (2004 e 2006) e Santos Jr., Ribeiro e Azevedo (2004).
} 
Tabela 4 - Deveres do Bom Cidadão (\%)

\begin{tabular}{l|c|c|c|c|c}
\hline \multicolumn{1}{c|}{ Opinião \% } & $\begin{array}{c}1 . \text { Nada } \\
\text { importante }\end{array}$ & 2 & 3 & 4 & $\begin{array}{c}\text { 5. Importan- } \\
\text { tíssimo }\end{array}$ \\
\hline $\begin{array}{l}\text { Votar sempre nas } \\
\text { eleições }\end{array}$ & 1,0 & 0,0 & 9,2 & 4,6 & 85,1 \\
\hline Pagar impostos & 2,3 & 2,3 & 9,2 & 9,2 & 77,1 \\
\hline $\begin{array}{l}\text { Obedecer sempre a leis } \\
\text { e regulamentos }\end{array}$ & 1,1 & 1,1 & 4,6 & 8,0 & 85,0 \\
\hline $\begin{array}{l}\text { Manter-se informado } \\
\text { sobre o governo }\end{array}$ & 1,1 & 2,3 & 13,8 & 5,7 & 77,0 \\
\hline $\begin{array}{l}\text { Participar em } \\
\text { associações e sindicatos }\end{array}$ & 6,9 & 5,7 & 29,9 & 19,5 & 37,9 \\
\hline Participar em partidos & 33,3 & 18,4 & 34,5 & 4,6 & 9,2 \\
\hline $\begin{array}{l}\text { Tentar compreender a } \\
\text { maneira de pensar das } \\
\text { pessoas que pensam } \\
\text { diferente }\end{array}$ & 1,1 & 1,1 & 8,0 & 19,5 & 70,1 \\
\hline $\begin{array}{l}\text { Escolher produtos por } \\
\text { razões éticas, políticas } \\
\text { ou ambientais, mesmo } \\
\text { que custem mais }\end{array}$ & 26,4 & 4,6 & 20,7 & 20,8 & 27,6 \\
\hline $\begin{array}{l}\text { Ajudar pessoas que } \\
\text { vivem pior que o sr. no } \\
\text { Brasil }\end{array}$ & 1,1 & 1,1 & 1,1 & 6,9 & 89,6 \\
\hline $\begin{array}{l}\text { Ajudar pessoas que } \\
\text { vivem pior no mundo }\end{array}$ & 1,1 & 2,3 & 8,0 & 11,5 & 77,0 \\
\hline
\end{tabular}

Fonte: Observatório das Metrópoles Núcleo Região Metropolitana de Maringá.

Tabela 4.1 - Médias comparadas ${ }^{8}$

\begin{tabular}{|c|c|c|c|}
\hline Cidade & Maringá & Sarandi & Paiçandu \\
\hline Votar sempre nas eleições & 3,7 & 3,7 & 3,6 \\
\hline Pagar impostos & 3,5 & 3,7 & 3,5 \\
\hline $\begin{array}{l}\text { Obedecer sempre a leis e } \\
\text { regulamentos }\end{array}$ & 3,6 & 4,0 & 4,0 \\
\hline $\begin{array}{l}\text { Manter-se informado sobre o } \\
\text { governo }\end{array}$ & 3,4 & 3,6 & 4,0 \\
\hline $\begin{array}{l}\text { Participar em associações e } \\
\text { sindicatos }\end{array}$ & 2,6 & 2,9 & 3,5 \\
\hline Participar em partidos & 1,2 & 1,6 & 2,3 \\
\hline $\begin{array}{l}\text { Tentar compreender a } \\
\text { maneira de pensar das } \\
\text { pessoas que pensam } \\
\text { diferente }\end{array}$ & 3,4 & 3,8 & 3,8 \\
\hline $\begin{array}{l}\text { Escolher produtos por razões } \\
\text { éticas, políticas ou } \\
\text { ambientais, mesmo que } \\
\text { custem mais }\end{array}$ & 2,2 & 1,9 & 2,3 \\
\hline $\begin{array}{l}\text { Ajudar pessoas que vivem } \\
\text { pior no Brasil }\end{array}$ & 3,7 & 4,0 & 4,0 \\
\hline
\end{tabular}

Indicador de 0 a 4 , onde 0 corresponde à nada importante e 4 à importantíssimo.

\footnotetext{
${ }^{8}$ Foram realizadas 63 entrevistas para Maringá, 18 em Sarandi e 6 em Paiçandu. Cada resposta obteve um peso e as médias correspondem a esse ranqueamento, obedecendo escalas que variam de 0 a 3 ou 4, conforme o indicado nas tabelas.
} 
No cômputo geral, as alternativas votar sempre nas eleições, obedecer sempre às leis e regulamentos, pagar impostos e manter-se informado sobre as atividades do governo foram consideradas muito importantes ou importantíssimas, detecta-se um perfil legalista dos entrevistados. Previsivelmente, já que o perfil dos entrevistados é o de pessoas vinculadas a atividades de apoio a segmentos vulneráveis, ajudar pessoas que vivem no Brasil pior do que o sr. (sra.) recebeu indicação alta também.

Considerando os dados da tabela 9, quando o questionamento refere-se à temática da participação, as freqüências diminuem e a participação em partidos foi considerada de alguma importância por apenas $13,8 \%$ dos entrevistados. Ao observarmos as médias, constatamos que é em Maringá que se encontra a menor indicação para a alternativa participar de associações e sindicatos e de partidos. No cômputo geral, nessa última cidade também aparecem as menores médias para as alternativas listadas: das 9, Maringá apresenta menor média em 6 delas. Paiçandu, em contraste, é a cidade na qual as lideranças mais valorizaram as alternativas: a menor média foi de 2,3.

Concluímos que as lideranças de Sarandi e, em maior medida as de Paiçandu, valorizam não apenas mais a participação em partidos e associações como também o conjunto das alternativas listadas. Nessas duas cidades, as lideranças, de maneira geral, manifestam-se mais apegadas às formas tradicionais de exercício da cidadania. 
Tabela 5 - Nível de concordância em relação às questões políticas

\begin{tabular}{|c|c|c|c|c|c|c|}
\hline $\begin{array}{l}\text { Opinião } \\
\%\end{array}$ & $\begin{array}{c}\text { Os partidos } \\
\text { políticos } \\
\text { incentivam as } \\
\text { pessoas a } \\
\text { serem } \\
\text { politicamente } \\
\text { ativas }\end{array}$ & $\begin{array}{c}\text { Mudança na } \\
\text { legislação } \\
\text { eleitoral } \\
\text { permitiria } \\
\text { que os } \\
\text { partidos } \\
\text { pudessem } \\
\text { cumprir } \\
\text { melhor seu } \\
\text { papel de } \\
\text { representar } \\
\text { interesses }\end{array}$ & $\begin{array}{c}\text { Os partidos } \\
\text { são } \\
\text { instituições } \\
\text { fundamentais } \\
\text { do regime } \\
\text { democrático }\end{array}$ & $\begin{array}{c}\text { Os } \\
\text { partidos } \\
\text { políticos } \\
\text { não dão } \\
\text { aos } \\
\text { eleitores } \\
\text { escolhas } \\
\text { políticas } \\
\text { reais }\end{array}$ & $\begin{array}{l}\text { Os partidos } \\
\text { poderiam ser } \\
\text { substituídos } \\
\text { por outros } \\
\text { instrumentos } \\
\text { de } \\
\text { representação }\end{array}$ & $\begin{array}{l}\text { O voto deve } \\
\text { deixar de } \\
\text { ser } \\
\text { obrigatório }\end{array}$ \\
\hline $\begin{array}{l}\text { 1. concorda } \\
\text { totalmente }\end{array}$ & 12,6 & 49,4 & 43,7 & 43,7 & 22,9 & 57,4 \\
\hline $\begin{array}{l}\text { 2. concorda } \\
\text { em parte }\end{array}$ & 32,2 & 25,3 & 33,3 & 29,9 & 24,1 & 17,2 \\
\hline $\begin{array}{l}\text { 3. nem } \\
\text { concorda } \\
\text { nem } \\
\text { discorda }\end{array}$ & 8,0 & 12,6 & 3,4 & 9,2 & 13,8 & 4,6 \\
\hline $\begin{array}{l}\text { 4. discorda } \\
\text { em parte }\end{array}$ & 25,3 & 10,3 & 12,6 & 10,3 & 9,2 & 3,4 \\
\hline $\begin{array}{l}\text { 5. discorda } \\
\text { totalmente }\end{array}$ & 21,8 & 2,3 & 6,9 & 6,9 & 29,9 & 17,2 \\
\hline Total geral & 100 & 100 & 100 & 100 & 100 & 100 \\
\hline
\end{tabular}

Tabela 5.1 - Médias comparadas

\begin{tabular}{l|c|c|c|c|c}
\hline Cidade & $\begin{array}{c}\text { Os partidos } \\
\text { incentivam as } \\
\text { pessoas a } \\
\text { serem } \\
\text { politicamente } \\
\text { ativas }\end{array}$ & $\begin{array}{c}\text { Os partidos } \\
\text { são } \\
\text { instituições } \\
\text { fundamentais } \\
\text { do regime } \\
\text { democrático }\end{array}$ & $\begin{array}{c}\text { Os } \\
\text { partidos } \\
\text { políticos } \\
\text { não dão } \\
\text { aos } \\
\text { eleitores } \\
\text { escolhas } \\
\text { políticas } \\
\text { reais }\end{array}$ & $\begin{array}{c}\text { Os partidos } \\
\text { poderiam ser } \\
\text { substituídos } \\
\text { por outros } \\
\text { instrumentos } \\
\text { de } \\
\text { representação }\end{array}$ & $\begin{array}{c}\text { Ob voto deve } \\
\text { deixar de } \\
\text { ser } \\
\text { obrigatório }\end{array}$ \\
\hline Maringá & 1,7 & 2,8 & 2,9 & 1,9 & 2,9 \\
\hline Sarandi. & 1,9 & 3,1 & 3,0 & 2,2 & 3,1 \\
\hline Paiçandu & 2,6 & 3,1 & 2,8 & 2,3 & 2,6 \\
\hline
\end{tabular}

Indicador de 0 a 4 , onde 0 corresponde à discordo totalmente e 4 à concordo totalmente.

Como se pode constatar pela tabela 5 , as lideranças reconhecem a importância dos partidos enquanto instituição, já que a maioria concorda totalmente ou em parte que os partidos são instituições fundamentais ao funcionamento do regime democrático. Por outro lado, tendem a avaliar negativamente sua atuação, pois apontam que os 
partidos políticos não dão aos eleitores escolhas políticas reais. Da mesma maneira, elas tenderam a discordar da opção sobre tornar o voto não obrigatório. Ou seja, a avaliação negativa sobre o sistema político pode não corresponder a uma postura de desvalorização de suas instituições. Reiterando dados anteriores, novamente as médias de Paiçandu revelam que ela é a cidade em que as lideranças apresentam opiniões relativamente mais favoráveis aos partidos.

Tabela 6 - Importância em votar nas eleições (\%)

\begin{tabular}{l|c|c|c}
\hline \multicolumn{1}{c|}{ Participação } & $\begin{array}{c}\text { Eleições } \\
\text { municipais }\end{array}$ & $\begin{array}{c}\text { Eleições } \\
\text { legislativas }\end{array}$ & $\begin{array}{c}\text { Eleições } \\
\text { presidenciais }\end{array}$ \\
\hline $\begin{array}{l}\text { 1. importantíssimo } \\
\text { 2. muito } \\
\text { importante }\end{array}$ & 70,1 & 56,3 & 67,8 \\
\hline 3. importante & 8,0 & 13,8 & 11,5 \\
\hline $\begin{array}{l}\text { 4. pouco } \\
\text { importante }\end{array}$ & 1,1 & 22,9 & 18,4 \\
\hline $\begin{array}{l}\text { 5. nada } \\
\text { importante }\end{array}$ & 0,0 & 5,7 & 2,3 \\
\hline Total geral & 100 & 1,1 & 0,0 \\
\hline \multicolumn{4}{|c|}{$\mathrm{N}=87$}
\end{tabular}

Fonte: Observatório das Metrópoles Núcleo Região Metropolitana de Maringá.

A maioria dos entrevistados considera importante ou importantíssimo votar nas eleições, mas há uma maior valorização das eleições municipais. A intimidade com as questões locais estimula o maior interesse. Por outro lado, as eleições legislativas são, relativamente, menos valorizadas. Assim, embora nesse universo possa haver uma valorização elevada em relação ao instrumento do voto, nele também se percebe reflexos da tendência presente na população em geral de priorizar o executivo. 
Tabela 6.1 - Participação em outros grupos (\%)

\begin{tabular}{l|c|c|c|c|c|c}
\hline \multicolumn{1}{c|}{ Participação } & $\begin{array}{c}\text { Partido } \\
\text { político }\end{array}$ & $\begin{array}{c}\text { Sindicato, } \\
\text { grêmio ou } \\
\text { associação } \\
\text { profissional }\end{array}$ & $\begin{array}{c}\text { Igreja ou } \\
\text { outra } \\
\text { organiza- } \\
\text { Ção } \\
\text { religiosa }\end{array}$ & $\begin{array}{c}\text { Grupo } \\
\text { desporti- } \\
\text { vo, cultural } \\
\text { ou } \\
\text { recreativo }\end{array}$ & $\begin{array}{c}\text { Outra associação } \\
\text { voluntária }\end{array}$ \\
\hline $\begin{array}{l}\text { 1. participa } \\
\text { ativamente }\end{array}$ & 8,0 & 11,5 & 58,6 & 26,4 & $\begin{array}{c}\text { se } \\
\text { participa não e } \\
\text { em } \\
\text { quantas }\end{array}$ & \\
\hline $\begin{array}{l}\text { 2. pertence, mas } \\
\text { não participa } \\
\text { ativamente }\end{array}$ & 10,3 & 12,6 & 16,1 & 14,9 & $\begin{array}{c}\text { sim em } \\
\text { uma }\end{array}$ & 24,1 \\
\hline $\begin{array}{l}\text { 3. já pertenceu } \\
\text { 4. nunca } \\
\text { pertenceu }\end{array}$ & 14,9 & 25,3 & 17,2 & 20,7 & $\begin{array}{c}\text { sim em } \\
\text { duas }\end{array}$ & 8,05 \\
\hline
\end{tabular}

Fonte: Observatório das Metrópoles Núcleo Região Metropolitana de Maringá.

Tabela 6.2 - Participação em outros grupos - médias

\begin{tabular}{c|c|c|c|c}
\hline Participação & $\begin{array}{c}\text { Partido } \\
\text { político }\end{array}$ & $\begin{array}{c}\text { Sindicato, } \\
\text { grêmio ou } \\
\text { associação } \\
\text { profissional }\end{array}$ & $\begin{array}{c}\text { Igreja ou outra } \\
\text { organização } \\
\text { religiosa }\end{array}$ & $\begin{array}{c}\text { Grupo } \\
\text { desportivo, } \\
\text { cultural ou } \\
\text { recreativo }\end{array}$ \\
\hline Maringá & 0,44 & 0,8 & 2,3 & 1,4 \\
\hline Sarandi & 0,83 & 1,0 & 1,8 & 1,0 \\
\hline Paiçandu & 1,5 & 0,5 & 2,3 & 0,83 \\
\hline
\end{tabular}

Indicador de 0 a 3 , onde 0 corresponde a nunca pertenceu; 1 corresponde a pertenceu mas não participa mais; 2 corresponde a pertence mas não participa e 3 corresponde a participa ativamente.

Como já se salientou anteriormente em relação ao perfil, a igreja ou outra organização religiosa é o número que sobressai entre as indicações de participação (58,6\%). Em segundo lugar, os entrevistados apontaram os grupos esportivos e culturais $(26,4 \%)$. Como se observa na tabela 6,67,8\% dos dirigentes das entidades disseram não ter outras experiências de participação além da sua entidade. Esse percentual se distribui de forma equivalente quando Maringá e Sarandi são tomadas em separado. No cômputo geral, consideramos significativa a ausência de outras experiências participativas nesse universo.

Os dados apontam baixa vinculação a partidos políticos, sindicatos e entidades profissionais, embora as médias apontem que os dirigentes de Sarandi e Paiçandu estejam mais vinculados a partidos do que os de Maringá. 
Tabela 7 - Mobilização Política (\%)

\begin{tabular}{l|c|c|c|c}
\hline \multicolumn{1}{c|}{ Ações } & $\begin{array}{c}\text { Fez no } \\
\text { último ano }\end{array}$ & $\begin{array}{c}\text { Fez nos } \\
\text { anos } \\
\text { anteriores }\end{array}$ & $\begin{array}{c}\text { Nunca fez } \\
\text { mas poderia } \\
\text { fazer }\end{array}$ & $\begin{array}{c}\text { Nunca } \\
\text { o faria }\end{array}$ \\
\hline $\begin{array}{l}\text { Assinar uma petição ou } \\
\text { fazer um abaixo-assinado }\end{array}$ & 26,4 & 29,9 & 31,0 & 12,6 \\
\hline $\begin{array}{l}\text { Boicotar ou comprar } \\
\text { determinados produtos, } \\
\text { por razões políticas, } \\
\text { éticas ou ambientais }\end{array}$ & 23,0 & 10,4 & 36,8 & 30,9 \\
\hline $\begin{array}{l}\text { Participar numa } \\
\text { manifestação }\end{array}$ & 17,4 & 29,1 & 33,7 & 19,8 \\
\hline $\begin{array}{l}\text { Contatar, ou tentar } \\
\text { contatar, um político ou } \\
\text { um funcionário do } \\
\text { governo para expressar } \\
\text { seu ponto de vista }\end{array}$ & 49,4 & 11,5 & 17,2 & 21,8 \\
\hline $\begin{array}{l}\text { Dar dinheiro ou tentar } \\
\text { recolher fundos para uma } \\
\text { causa pública }\end{array}$ & 48,3 & 18,4 & 19,5 & 13,8 \\
\hline $\begin{array}{l}\text { Contatar ou aparecer na } \\
\text { mídia para exprimir as } \\
\text { suas opiniões }\end{array}$ & 33,3 & 16,0 & 29,9 & 20,7 \\
\hline $\begin{array}{l}\text { Participar num fórum ou } \\
\text { grupo de discussão } \\
\text { através da internet }\end{array}$ & 11,5 & 4,6 & 64,4 & 19,5 \\
\hline $\begin{array}{l}\text { Participar em comício ou } \\
\text { reunião política }\end{array}$ & 31,0 & 37,9 & 13,8 & 17,2 \\
\hline $\begin{array}{l}\text { Participar de greve } \\
\text { Fonte: Observatório das }\end{array}$ & 2,3 & 18,4 & 28,7 & 50,6 \\
\hline & & & & \\
\hline
\end{tabular}

Fonte: Observatório das Metrópoles Núcleo Região Metropolitana de Maringá.

Tabela 7.1 - Mobilização política - Médias

\begin{tabular}{l|c|c|c}
\hline \multicolumn{1}{c|}{ Cidade } & Maringá & Sarandi & Paiçandu \\
\hline Assinar petição & 1,7 & 1,6 & 1,5 \\
\hline $\begin{array}{l}\text { Boicotar produtos por razões éticas ou } \\
\text { políticas }\end{array}$ & 1,2 & 1,1 & 1,5 \\
\hline Participar de manifestação & 1,4 & 1,3 & 1,16 \\
\hline $\begin{array}{l}\text { Participar de comício ou reunião } \\
\text { política }\end{array}$ & 1,6 & 2,3 & 2,0 \\
\hline $\begin{array}{l}\text { Contatar político ou alguém do } \\
\text { governo para expressar opinião }\end{array}$ & 1,8 & 2,0 & 1,6 \\
\hline Dar dinheiro para causa pública & 1,9 & 2,1 & 2,0 \\
\hline Contatar ou aparecer na mídia & 1,7 & 1,3 & 1,16 \\
\hline Fórum discussão internet & 1,0 & 1,0 & 1,0 \\
\hline Greve & 0,79 & 0,5 & 0,66 \\
\hline
\end{tabular}

Indicador de 0 a 3 , onde 0 corresponde a nunca o faria e 3 a fez no último ano.

Os números da tabela 7 indicam que os informantes são pessoas ativas nas diversas modalidades de mobilização listadas, e o tipo de ação política mais rejeitado é a greve. Apontam-se 2 itens como 
novidades na prática associativa: boicotar ou comprar determinados produtos por razões políticas, éticas ou ambientais e participar em fóruns ou grupos de discussão através da internet. No primeiro caso, $33 \%$ fizeram no último ano ou em anos anteriores, e $36,8 \%$ poderiam fazer. No segundo caso, apenas $16 \%$ dos entrevistados tiveram participação, mas admitiram poder realizar tal atividade no futuro $64,4 \%$.

Arrisca-se a afirmar que os dados apontam pistas do movimento constitutivo de matizes do que vem sido chamado da Nova Cultura Política. As informações como as contidas na tabela 7 corroboram essa hipótese. Realizar ou admitir a possibilidade de realizar tais ações aponta, sem dúvida, mudanças de comportamento no sentido de um envolvimento mais individual dos entrevistados. Os autores que tratam do tema (CLARK e HOFFMAN-MARTINOT, 1998; CABRAL e SILVA, 2006) identificam essa nova tendência de exercício da cidadania (em contraposição aos caminhos apontados por Marshall, por exemplo) de forma mais individualizada e horizontal. Ou seja, a manifestação ocorre por meio do comportamento do indivíduo e não necessariamente em uma participação coletiva, via movimentos sociais e/ou organizações.

Algumas indicações chamam a atenção se cruzadas com outras. Verificou-se acima que a participação em partidos e associações é baixa nesse segmento, mas a opção participar em comícios ou reunião política recebeu $68 \%$ das respostas se somadas as opções fez no último ano e fez em anos anteriores, o que indica um envolvimento pontual em questões diretamente vinculadas ao mundo da política e não uma total negação da política. Vale a pena chamar a atenção que, em Maringá, essa opção recebeu a menor média. Também pelas médias se observa que nessa cidade as lideranças se sentem mais propícias a fazer uso da mídia para manifestar sua opinião. 
Tabela 8 - Confiança Política (\%)

\begin{tabular}{l|c|c|c}
\hline $\begin{array}{c}\text { Opinião } \\
\%\end{array}$ & $\begin{array}{c}\text { No congresso } \\
\text { nacional estão } \\
\text { representados os } \\
\text { interesses que } \\
\text { compõem a } \\
\text { sociedade brasileira }\end{array}$ & $\begin{array}{c}\text { É possível exercer } \\
\text { pressão sobre os } \\
\text { deputados do } \\
\text { congresso nacional } \\
\text { para expressar } \\
\text { opiniões/fazer } \\
\text { reivindicações }\end{array}$ & $\begin{array}{c}\text { A administração } \\
\text { pública no } \\
\text { Brasil está } \\
\text { comprometida } \\
\text { em servir as } \\
\text { pessoas }\end{array}$ \\
\hline $\begin{array}{l}\text { 0. NS/NR } \\
\text { 1. concorda } \\
\text { totalmente }\end{array}$ & 1,1 & 1,1 & 0,0 \\
\hline $\begin{array}{l}\text { 2. concorda em } \\
\text { parte }\end{array}$ & 20,7 & 39,1 & 18,4 \\
\hline $\begin{array}{l}\text { 3. nem } \\
\text { concorda nem } \\
\text { discorda }\end{array}$ & 40,2 & 35,6 & 36,8 \\
\hline $\begin{array}{l}\text { 4. discorda em } \\
\text { parte }\end{array}$ & 4,6 & 8,7 & 23,0 \\
\hline $\begin{array}{l}5 . \text { discorda } \\
\text { totalmente }\end{array}$ & 19,5 & 10,3 & 17,2 \\
\hline \multicolumn{1}{c|}{ Total } & 13,8 & 100 & 100 \\
\hline
\end{tabular}

Fonte: Observatório das Metrópoles Núcleo Região Metropolitana de Maringá.

Chama a atenção que em Maringá há o maior percentual de lideranças que discordam totalmente ou em parte que a administração pública no Brasil está comprometida em servir as pessoas: 42,8\%, enquanto que para as mesmas alternativas, em Sarandi o percentual foi de 27,8 e em Paiçandu, 33,34. Ao cruzar com a percepção de qual grupo ou instituições representam melhor seus interesses (Tabela 12), os políticos aparecem com baixa confiabilidade e, no caso em tela, o Congresso Nacional aparece como altamente permeável às pressões.

Tabela 9 - Avaliação da Democracia no Brasil (\%)

\begin{tabular}{c|c|c|c}
\hline Participação & $\begin{array}{c}\text { Como avalia o } \\
\text { funcionamento } \\
\text { da democracia } \\
\text { hoje no Brasil? }\end{array}$ & $\begin{array}{c}\text { Como avalia o } \\
\text { funcionamento da } \\
\text { democracia no } \\
\text { Brasil há 10 anos } \\
\text { atrás? }\end{array}$ & $\begin{array}{c}\text { E daqui a 10 anos, } \\
\text { como pensa que vai } \\
\text { ser o } \\
\text { funcionamento da } \\
\text { democracia no } \\
\text { Brasil? }\end{array}$ \\
\hline 1. muito ruim & 8,0 & 21,8 & 8,0 \\
\hline 2. & 13,8 & 32,2 & 8,0 \\
\hline 3. & 52,9 & 34,5 & 23,0 \\
\hline 4. & 21,8 & 9,2 & 25,3 \\
\hline Total & 3,4 & 2,3 & 100 \\
\hline
\end{tabular}

Fonte: Observatório das Metrópoles Núcleo Região Metropolitana de Maringá. 
Tabela 10 - Opinião em relação à democracia (\%)

\begin{tabular}{|c|c|}
\hline Opinião & $\%$ \\
\hline A democracia é um regime bom & 91,9 \\
\hline É indiferente que o regime seja democrático ou não & 8,1 \\
\hline Total & 100 \\
\hline
\end{tabular}

$\mathrm{N}=87$

Fonte: Observatório das Metrópoles Núcleo Região Metropolitana de Maringá.

Ao se comparar a trajetória da democracia brasileira com a das democracias consolidadas, o quadro que se tem é o de um crescente acúmulo de direitos e de volume de participação. Segundo dados de Resende e Tafner (2005), no período compreendido entre 1982 e 2002, o eleitorado cresceu 20,9\%. Verificou-se, também, uma diminuição acentuada das diferenças regionais na participação. Norte e Nordeste passam a participar de forma mais equilibrada do processo e indicam uma redução nos custos de participar das eleições nas áreas mais pobres.

As últimas décadas apresentam um saldo importante no processo de construção da democracia, pois apesar das deficiências, os países latino americanos não optaram por novos arranjos autoritários e, um dado importante, as populações, no momento de identificar responsáveis pelo mau desempenho global, diferenciam cada vez mais as diversas instituições, segundo pesquisa desenvolvida por Guillermo O'Donnell, financiada pelo PNUD e intitulada A Democracia na América Latina (2004) com 18 países da América Latina. Por outro lado, na indagação global acerca do valor da democracia, para 56,3\% dos entrevistados, o desenvolvimento econômico é mais importante que a democracia, e 54,7\% disseram que apoiariam um governo autoritário se este resolvesse os problemas econômicos. No Brasil, quase metade dos entrevistados apresentaram uma posição ambivalente a respeito da democracia: democratas 30,6\%; não-democratas $27,0 \%$ e ambivalentes 35,6\%. Na Argentina, 51,5\% democratas, 31,8 \% não-democratas e $17 \%$ ambivalentes. A indicação de ambivalência significa que a população dá mais valor ao desenvolvimento do que à democracia e, 
inclusive, retiraria seu apoio a um governo democrático se ele fosse incapaz de resolver seus problemas econômicos (PNUD, 2004, p. 28).

No caso dos representantes das entidades assistenciais, um público qualificado e atuante nos espaços públicos, no total obteve-se uma avaliação altamente positiva da democracia, que é considerada por $92 \%$ como um regime bom. Quanto ao funcionamento da democracia (Tabela 9), a manifestação aponta otimismo quanto ao futuro da democracia, com os entrevistados acreditando que será um regime muito melhor que no passado e melhor que no presente.

Tabela 11 - Posição no espectro político (\%)

\begin{tabular}{c|c}
\hline Nível de interesse & $\%$ \\
\hline 1. esquerda & 8,0 \\
\hline 2. & 10,3 \\
\hline 3. & 49,4 \\
\hline 4. & 20,7 \\
\hline 5. direita & 11,5 \\
\hline Total & 100 \\
\hline \multicolumn{2}{|c|}{$\mathrm{N}=87$}
\end{tabular}

Fonte: Observatório das Metrópoles Núcleo Região Metropolitana de Maringá.

As lideranças, na sua maioria, consideram-se de centro-direita, optando pelos números 3,4 e 5 . O que chama a atenção é que em Sarandi as opções se concentraram em centro-direita e centroesquerda. Outro dado a destacar é que, enquanto em Maringá há lideranças que se consideraram de centro-esquerda, essa alternativa não aparece nenhuma vez para as lideranças de Paiçandu: todas elas se dizem de centro ou de direita.

Tabela 12 - Instituições ou grupos que melhor defendem interesses (\%)

\begin{tabular}{l|c|c}
\hline Instituições/grupos & Primeira & Segunda \\
\hline Nenhuma & 2,3 & 14,9 \\
\hline Políticos & 6,9 & 4,6 \\
\hline Partidos & 0,0 & 2,3 \\
\hline Juízes & 3,4 & 3,4 \\
\hline $\begin{array}{l}\text { Sindicatos e associações } \\
\text { profissionais }\end{array}$ & 16,1 & 11,5 \\
\hline Igrejas ou cultos religiosos & 29,9 & 16,1 \\
\hline ONGs & 23,0 & 14,9 \\
\hline Ministério Público & 16,1 & 27,6 \\
\hline Outras associações & 2,3 & 4,6 \\
\hline \multicolumn{1}{|c|}{ Total } & 100 & 100 \\
\hline
\end{tabular}

N=87 Fonte: Observatório das Metrópoles Núcleo Região Metropolitana de Maringá. 
No caso acima, solicitou-se aos entrevistados que apontassem as instituições ou grupos que melhor defendem seus interesses em primeiro e segundo lugares. As instituições que receberam maior número de indicações foram pela ordem as igrejas e cultos religiosos, as ONGs, os sindicatos e associações profissionais e o Ministério Público. Destaque-se que o Ministério Público aparece como a segunda instituição de maior confiança para $27,6 \%$ dos entrevistados. Entendese que o relacionamento e a conquista da confiança por parte do Ministério Público é um fenômeno recente e em fase de construção.

Tabela 13 - Avaliação do Conselho Municipal de Assistência Social, Maringá,

\begin{tabular}{|c|c|c|}
\hline Opinião & Principal & Secundário \\
\hline NS/NR & 1,1 & 46,1 \\
\hline $\begin{array}{l}\text { Cumpre em parte as atribuições que são de sua } \\
\text { competência }\end{array}$ & 40,5 & 0,0 \\
\hline $\begin{array}{l}\text { É ineficiente no cumprimento de suas atribuições } \\
\text { como fiscalizar, acompanhar, propor e deliberar } \\
\text { sobre os temas da área }\end{array}$ & 4,5 & 1,1 \\
\hline $\begin{array}{l}\text { Exerce um papel importante na definição da } \\
\text { política de assistência social do município, } \\
\text { fiscalizando, acompanhando e deliberando sobre } \\
\text { temas da área }\end{array}$ & 32,6 & 6,7 \\
\hline $\begin{array}{l}\text { Poderia ser mais eficiente se tivesse mais apoio } \\
\text { do poder municipal }\end{array}$ & 10,1 & 16,8 \\
\hline $\begin{array}{l}\text { Poderia ser mais eficiente se as entidades da } \\
\text { sociedade civil participassem mais ativamente }\end{array}$ & 11,3 & 29,2 \\
\hline Total & 100 & 100 \\
\hline
\end{tabular}

Fonte: Observatório das Metrópoles Núcleo Região Metropolitana de Maringá.

A solicitação foi que os entrevistados fizessem dois apontamentos a respeito do funcionamento do conselho de Assistência Social e o resultado demonstra uma leitura positiva das atividades se somados os itens 1 e 2 da opinião principal, consideram que o Conselho cumpre em

\footnotetext{
${ }^{9} \mathrm{~A}$ inclusão dessas informações sobre a percepção que os dirigentes têm do Conselho de Assistência Social ocorreu por sugestão dos colegas presentes na sessão 3B, da área temática Cultura Política e Democracia do 6. Encontro da ABCP, 2008.
} 
parte as atribuições que são de sua competência $(40,4 \%)$ e exerce um papel importante na definição da política (...) (32,6\%). Detecta-se, no entanto, uma crítica à atuação de seu próprio segmento, pois na opinião secundária verifica-se que $29,2 \%$ do entrevistados estão descontentes com a atuação das entidades da sociedade civil. As opiniões confirmam o que o contato com o cotidiano dos conselhos de assistência pesquisados apontam, ou seja, os conselhos funcionam, têm responsabilidade para com a política de assistência nas tarefas de acompanhamento e fiscalização, mas ficam burocratizados em seu cotidiano.

Tabela 14 - Interesse na política e auto-percepção do quanto está informado sobre ela (\%)

\begin{tabular}{l|c|c|c|c}
\hline \multicolumn{1}{c|}{ Opinião } & $\begin{array}{c}\text { Eu não tenho } \\
\text { nada a dizer } \\
\text { sobre o que o } \\
\text { governo faz }\end{array}$ & $\begin{array}{c}\text { Eu acho } \\
\text { que o } \\
\text { governo } \\
\text { não liga } \\
\text { muito para } \\
\text { o que } \\
\text { pessoas } \\
\text { como eu } \\
\text { pensam }\end{array}$ & $\begin{array}{c}\text { Eu acho que } \\
\text { tenho boa } \\
\text { compreensão } \\
\text { dos assuntos } \\
\text { políticos que } \\
\text { são } \\
\text { importantes } \\
\text { para o Brasil }\end{array}$ & $\begin{array}{c}\text { Eu penso que a } \\
\text { maioria das } \\
\text { pessoas no } \\
\text { brasil está } \\
\text { melhor } \\
\text { informada do } \\
\text { que eu sobre a } \\
\text { política e o } \\
\text { governo }\end{array}$ \\
\hline $\begin{array}{l}\text { 1. concorda } \\
\text { totalmente }\end{array}$ & 0,0 & 23,0 & 57,5 & 4,6 \\
\hline 2. concorda em parte & 13,8 & 40,2 & 33,3 & 24,1 \\
\hline $\begin{array}{l}\text { 3. nem concorda nem } \\
\text { discorda }\end{array}$ & 4,6 & 4,6 & 4,6 & 11,5 \\
\hline 4. discorda em parte & 19,5 & 23,0 & 3,4 & 27,6 \\
\hline 5. discorda totalmente & 62,1 & 9,2 & 1,1 & 32,2 \\
\hline \multicolumn{1}{c|}{ Total } & 100 & 100 & 100 & 100 \\
\hline \multicolumn{4}{l}{$\mathrm{N}=87$}
\end{tabular}

Fonte: Observatório das Metrópoles Núcleo Região Metropolitana de Maringá.

Os dados apontam que os informantes se consideram pessoas relativamente integradas e informadas das questões políticas e capazes de influenciar decisões. Frente à afirmação eu não tenho nada a dizer sobre o que o governo faz, a soma de discorda em parte e discorda totalmente resulta em $81,6 \%$. A afirmação de eu acho que tenho boa compreensão dos assuntos políticos que são importantes para o Brasil teve a discordância em todo ou em parte de $90,8 \%$ dos entrevistados. 
Tabela 15 - Opinião sobre instrumentos de aferição da vontade pública (\%)

\begin{tabular}{l|c|c|c|c}
\hline Participação & $\begin{array}{c}\text { Através do } \\
\text { voto, os } \\
\text { cidadãos } \\
\text { transferem } \\
\text { para o } \\
\text { candidato eleito } \\
\text { o poder de } \\
\text { decidir por eles }\end{array}$ & $\begin{array}{c}\text { O orçamento } \\
\text { municipal deveria } \\
\text { ser elaborado } \\
\text { com a } \\
\text { participação } \\
\text { direta dos } \\
\text { cidadãos }\end{array}$ & $\begin{array}{c}\text { O plebiscito é } \\
\text { uma boa } \\
\text { maneira de } \\
\text { decidir } \\
\text { questões } \\
\text { políticas } \\
\text { importantes }\end{array}$ & $\begin{array}{c}\text { Os cidadãos } \\
\text { poderem } \\
\text { participar em } \\
\text { ações de } \\
\text { desobediên- } \\
\text { cia civil }\end{array}$ \\
\hline $\begin{array}{l}\text { 1. concorda } \\
\text { totalmente }\end{array}$ & 54,0 & 60,9 & 60,9 & 18,4 \\
\hline $\begin{array}{l}\text { 2. concorda } \\
\text { em parte }\end{array}$ & 33,3 & 25,3 & 28,7 & 27,6 \\
\hline $\begin{array}{l}\text { 3. nem } \\
\text { concorda nem } \\
\text { discorda }\end{array}$ & 1,1 & 6,9 & 6,9 & 6,9 \\
\hline $\begin{array}{l}\text { 4. discorda } \\
\text { em parte }\end{array}$ & 3,4 & 5,7 & 1,1 & 17,2 \\
\hline $\begin{array}{l}5 . \text { discorda } \\
\text { totalmente }\end{array}$ & 8,1 & 1,1 & 100 & 100 \\
\hline \multicolumn{1}{c|}{ Total } & 100 & 100 & $\mathrm{~N}=87$ &
\end{tabular}

Fonte: Observatório das Metrópoles Núcleo Região Metropolitana de Maringá.

A ação de desobediência civil aparece, sem dúvida, como uma questão que polarizou os entrevistados: aqueles que discordam em parte ou discordam totalmente somaram $47,1 \%$ e, na outra ponta, os que concordam totalmente ou em parte somaram 46,0\%. Não deve causar estranhesa a dificuldade de se lidar com o fato de subverter uma determinada ordem no seio de um segmento estruturado em bases de forte religiosidade e altamente comprometido com a estruturação social. Por outro lado, perpassa o campo o sentimento de que mudanças estruturais não ocorrerão caso indivíduos-cidadãos não atuem de forma mais incisiva. A discussão acerca da desobediência civil não é nova. Lembra Vieira (1984) que da desobediência civil somente participam os cidadãos, indivíduos possuidores de direitos e obrigações perante o Estado. Estão excluídos aqueles que somente obedecem. Ainda que em nossa sociedade os direitos de cidadania estejam formalmente garantidos, vale resgatar as reflexões de La Boétie (1530-1563) (1982) que, em seu Discurso da Servidão Voluntária, aponta que o tirano só se manteria no poder se houvesse o consentimento, o voluntarismo dos oprimidos, dos insatisfeitos. 


\section{Temas polêmicos}

Os entrevistados foram convidados a se manifestar diante de temas delicados e contemporâneos, alguns discutidos à exaustão pelos meios de comunicação ${ }^{10}$. O ponto de partida para tal abordagem é a constatação de que os dirigentes de entidades assistenciais lidam direta ou indiretamente com o assunto. Há inúmeras entidades que atendem adolescentes e jovens com problemas de dependência, assim sendo, as temáticas da legalização do aborto, da diminuição da idade penal e da descriminalização da maconha criaram a expectativa de que tivessem essas questões elaboradas.

Tabela 16 - Nível de concordância em relação às questões polêmicas em discussão na sociedade

\begin{tabular}{l|c|c|c|c|c|c}
\hline Participação & $\begin{array}{c}\text { Legaliza- } \\
\text { ção da } \\
\text { união de } \\
\text { pessoas do } \\
\text { mesmo } \\
\text { sexo }\end{array}$ & $\begin{array}{c}\text { Insti- } \\
\text { tuição } \\
\text { da } \\
\text { pena } \\
\text { de } \\
\text { morte }\end{array}$ & $\begin{array}{c}\text { Legali- } \\
\text { zação } \\
\text { da } \\
\text { maco- } \\
\text { nha }\end{array}$ & $\begin{array}{c}\text { Legaliza- } \\
\text { ção do } \\
\text { aborto }\end{array}$ & $\begin{array}{c}\text { Diminui- } \\
\text { ção da } \\
\text { maiori- } \\
\text { dade } \\
\text { penal }\end{array}$ & $\begin{array}{c}\text { Cotas } \\
\text { para } \\
\text { segmen- } \\
\text { tos na } \\
\text { univer- } \\
\text { sidade }\end{array}$ \\
\hline $\begin{array}{l}\text { 1. concorda } \\
\text { totalmente }\end{array}$ & 12,6 & 2,3 & 3,4 & 3,4 & 43,7 & 31,0 \\
\hline $\begin{array}{l}\text { 2. concorda } \\
\text { em parte }\end{array}$ & 8,0 & 19,5 & 8,0 & 11,5 & 10,3 & 16,1 \\
\hline $\begin{array}{l}\text { 3. nem } \\
\text { concorda nem } \\
\text { discorda }\end{array}$ & 10,3 & 2,3 & 5,7 & 0,0 & 4,6 & 5,7 \\
\hline $\begin{array}{l}4 . \text { discorda em } \\
\text { parte }\end{array}$ & 8,0 & 10,3 & 5,7 & 8,0 & 13,8 & 10,3 \\
\hline $\begin{array}{l}5 . \text { discorda } \\
\text { totalmente }\end{array}$ & 55,2 & 63,2 & 73,6 & 75,9 & 25,3 & 34,5 \\
\hline $\begin{array}{l}\text { 6. não } \\
\text { respondeu }\end{array}$ & 5,7 & 2,3 & 3,4 & 1,1 & 2,3 & 2,3 \\
\hline \multicolumn{1}{c|}{ Total } & 100 & 100 & 100 & 100 & 100 & 100 \\
\hline
\end{tabular}

Fonte: Observatório das Metrópoles Núcleo Região Metropolitana de Maringá.

\footnotetext{
${ }^{10}$ As questões foram inspiradas na pesquisa da Fundação Perseu Abramo/ Núcleo de Opinião Pública - Cultura Política e Cidadania I, de Novembro de 1997.
} 
Tabela 17 - Opinião em relação às pessoas que defendem

\begin{tabular}{|c|c|c|c|c|c|c|}
\hline Opinião & \begin{tabular}{|c|} 
Legalização \\
da união \\
entre \\
pessoas do \\
mesmo \\
sexo \\
\end{tabular} & $\begin{array}{l}\text { Instituição da } \\
\text { pena de morte }\end{array}$ & $\begin{array}{c}\text { Legalização } \\
\text { da maconha }\end{array}$ & $\begin{array}{c}\text { Legalização do } \\
\text { aborto }\end{array}$ & $\begin{array}{c}\text { Diminuição } \\
\text { da maiorida- } \\
\text { de penal }\end{array}$ & Cotas \\
\hline $\begin{array}{c}\text { Podem ser } \\
\text { a favor } \\
\text { dessa idéia, } \\
\text { desde que } \\
\text { não tentem } \\
\text { convencer } \\
\text { os demais } \\
\end{array}$ & 64,4 & 66,6 & 70,1 & 70,1 & 34,5 & 34,5 \\
\hline $\begin{array}{c}\text { Devem } \\
\text { simplesmen } \\
\text { te seguir o } \\
\text { que pensa } \\
\text { a maioria }\end{array}$ & 3,4 & 5,7 & 4,6 & 1,1 & 4,6 & 5,7 \\
\hline $\begin{array}{c}\text { Podem } \\
\text { tentar } \\
\text { convencer } \\
\text { as pessoas } \\
\text { dessa idéia } \\
\end{array}$ & 18,4 & 19,5 & 11,5 & 14,9 & 55,2 & 51,7 \\
\hline NS/NR & 10,3 & 5,7 & 10,3 & 10,3 & 3,4 & 6,9 \\
\hline Outras & 3,4 & 2,3 & 3,4 & 3,4 & 2,3 & 1,1 \\
\hline Total & 100 & 100 & 100 & 100 & 100 & 100 \\
\hline
\end{tabular}

Fonte: Observatório das Metrópoles Núcleo Região Metropolitana de Maringá.

O conjunto de respostas indica uma realidade um tanto distinta. Inúmeras situações apontaram total discordância da proposição: união entre pessoas do mesmo sexo, 55,2\%; liberalização da maconha, 75,9\%; legalização do aborto, 75,9\%; instituição da pena de morte, $63,2 \%$.

Quando o assunto é diminuição da maioridade penal e cotas para segmentos na universidade, verifica-se uma polarização entre os que concordam totalmente ou em parte e os que discordam totalmente ou em parte, conforme Tabela 17.

A cultura religiosa deu a tônica à maioria das respostas dos dirigentes entrevistados. Evocaram Deus para justificar as respostas sobre a instituição da pena de morte e a legalização do aborto. Os entrevistados registraram inúmeras reações que podem ser sintetizadas na frase Deus deu a vida e só Ele pode tirar

A tabela seguinte reúne a opinião das pessoas sobre aqueles que pensam diferente. Buscou-se averiguar o índice de tolerância para com 
o outro. A questão de fundo que estimulou tal propositura é um dos princípios que permite a sobrevivência de uma democracia pluralista no sentido apontado por Mouffe (1996, p. 15) "lutamos contra suas idéias, mas não poremos em causa o seu direito de defendê-los". A pouca tolerância em relação a pessoas que defendem temas polêmicos foi tendência principal das respostas: $67,8 \%$ na média responderam que as pessoas podem ser a favor, desde que não tentem convencer as demais. Já a resposta podem tentar (têm o direito de) convencer as pessoas dessa idéia recebeu em média $16 \%$ das respostas. A resposta do item não sabe/não respondeu recebeu na média $9,2 \%$ e outras em torno dos $3 \%$. A conclusão, levando em conta não só as respostas, mas também o comportamento dos entrevistados quando receberam a equipe de campo, é que os números representam a recusa em tratar temas delicados.

\section{Considerações finais}

A pesquisa teve como objetivo contribuir para um maior conhecimento dos atores políticos fundamentais na área da assistência social, que são os dirigentes das entidades assistenciais. Além disso, buscou-se apresentar uma metodologia para análise do comportamento político, traduzido em termos da cultura política dos dirigentes.

As lideranças entrevistadas apresentaram comportamentos conservadores e legalistas diante de questionamentos que os instigaram a assumir posicionamentos. Mostraram-se informados no que diz respeito à vida pública e consideraram ter alguma capacidade de intervenção.

Diante da temática da cultura política, algumas pistas foram deixadas no sentido de assumirem posturas que caracterizam a nova cultura política. Aceitar participar de fóruns na internet e listas de discussão, assim como boicotar produtos por razões éticas ou políticas são algumas das manifestações. Chama-nos atenção a comparação entre os municípios, quando as médias são tiradas, as respostas de Maringá sempre se apresentam mais diluídas do que as das outras duas. Atribui-se ao fato de um centro maior dar maiores opções de 
comportamentos e instituições. Um bom exemplo são os partidos políticos: em centros maiores, as agremiações estruturadas tendem a ter maior importância na vida das lideranças à medida que são intensamente chamadas a participar diretamente, saindo candidatas a cargos como de vereador ou a apoiar este ou aquele candidato. Nos municípios maiores há uma maior oferta de quadros ${ }^{11}$.

Os dados aqui apresentados têm muito mais a intenção de contribuir para que esse tema ganhe espaço no debate. Eles jogam algumas pistas que, exploradas, podem servir de base para a elaboração de perguntas não apenas sobre o papel que têm assumido as entidades de assistência no conjunto das mudanças ocorridas na política da assistência social, como também sobre as possíveis especificidades que caracterizam esse segmento associativo no contexto mais amplo da sociedade civil brasileira.

Celene Tonella é professora associada do Departamento de Ciências Sociais e do Programa de Mestrado em Ciências Sociais da Universidade Estadual de Maringá e Pesquisadora do Observatório das Metrópoles Núcleo Região Metropolitana de Maringá.

E-mail: ctonella@uol.com.br

\section{Referências:}

ALMOND, Gabriel; VERBA, Sidney. The civic culture. Newburry Park: Sage, 1963.

AVRITZER, Leonardo. Modelos de deliberação democrática: uma análise do orçamento participativo no Brasil. In: SANTOS, Boaventura de Souza (Org.). Democratizar a democracia - os caminhos da democracia participativa. Rio de Janeiro: Civilização Brasileira, 2002. p. 561-598.

BRASIL. Lei n. 8.742, de 7 de dezembro de 1993. Lei orgânica da assistência social (LOAS). Dispõe sobre a Organização da Assistência social e dá outras providências. Disponível em: <http://www.mdes.gov.br/legislação>. Acesso em: 25 mai. 2008.

\footnotetext{
${ }^{11}$ Essa tendência a pulverização/concentração de médias conforme tamanho de municípios foi detectado em outras pesquisas realizadas pela rede do Observatório das Metrópoles.
} 
. Lei no 9.790 de 1999 - Lei das Oscips. Dispõe sobre a qualificação de pessoas jurídicas de direito privado, sem fins lucrativos, como Organizações da Sociedade Civil de Interesse Público, institui e disciplina o Termo de Parceria, e dá outras providências. In: Ministério da Fazenda. Disponível em: <http://www.fazenda.gov.br/spe/publicações>. Acesso em: $15 \mathrm{dez}$. 2008.

Resolução 191, de 10 de novembro de 2005 do Conselho Nacional de Assistência Social. Institui orientação para regulamentação do art. $3^{\circ}$ da Lei Federal no 8.742, de 07 de dezembro de 1993 - LOAS, acerca das entidades e organizações de assistência social mediante a indicação das suas características essenciais. Disponível em: <http://www.mds.gov.br/cnas/legislação>. Acesso em: 15 dez. 2008.

CABRAL, Manuel Villaverde; SILVA, Felipe Carreira. O "efeito metrópole" sobre o exercício da cidadania política, 2006. mimeo.

CARVALHO, José Murilo de. A cidadania no Brasil: o longo caminho. Rio de Janeiro: Civilização Brasileira, 2004.

CASTRO, Henrique C. de Oliveira. Cultura política, democracia e hegemonia: uma tentativa de explicação do comportamento político não-democrático, $\mathrm{s} / \mathrm{d}$. Disponível em: <http://www.artnet.com.br/ gramsci/arqiv67.htm>. Acesso em: 01. fev. 2007.

CLARK, Terry Nichels; HOFFMAN-MARTINOT, Vicent. The new political culture. Boulder Colo: Westview Press, 1998.

COSTA, Sérgio. Esfera pública, redescoberta da sociedade civil e movimentos sociais no Brasil. Novos Estudos Cebrap, São Paulo, n. 38, p. 38-52, mar. 1994.

DOIMO, Ana Maria. Pluralidade religiosa à brasileira, associativismo e movimentos sociais em São Paulo. In: AVRITZER, Leonardo (Org.). $A$ participação em São Paulo. São Paulo: Editora da UNESP, 2004. p. 123196.

FEDOZZI, Luciano. Orçamento Participativo. Porto Alegre: Tomo Editorial, 1997.

FUNDAÇÃO PERSEU ABRAMO. Núcleo de Opinião Pública - Cultura Política e Cidadania I, de Novembro de 1997. Disponível em: <http:www2.fpa.org.br/portal>. Acesso em: 25 mai. 2008.

GENRO, Tarso; SOUZA, Ubiratan. Orçamento Participativo: a experiência de Porto Alegre. São Paulo: Editora Perseu Abramo, 1997. 
GOHN, Maria da Glória. Conselhos populares e participação popular. Serviço Social e Sociedade, São Paulo, v. IX, n. 26, p. 25-47, 1990.

HELD, David. Modelos de democracia. Belo Horizonte: Paidéia, 1987.

IBGE. População. Disponível em:<http://www.ibge.gov.br $>$. Acesso em 12 dez. 2007.

KRISCHKE, Paulo. Aprendendo a democracia na América Latina. Atores sociais e mudança cultural. Porto Alegre: EDPUCRS, 2004.

LA BOÈTIE, Etienne de. Discurso da Servidão Voluntária. São Paulo: Brasiliense, 1982.

MARSHALL, Thomas Humprey. Cidadania, classe social e status. Rio de Janeiro: Zahar, 1967.

MOUFFE, Chantal. O regresso do político. Lisboa: Ed. Gradiva, 1996.

PATEMAN, Carole. Participação e teoria democrática. São Paulo: Paz e Terra, 1992.

PERISSINOTTO, Renato M. Participação e democracia: o caso do conselho municipal de assistência social de Curitiba. In: PERISSINOTTO, Renato; FUKS, Mario, (Orgs.). Democracia: teoria e prática. Rio de Janeiro: Relume Dumará, 2002. p. 245-272.

PNUD - PROGRAMA DAS NAÇÕES UNIDAS PARA O DESENVOLVIMENTO. Relatório A democracia na América Latina - rumo a uma democracia de cidadãs e cidadãos. São Paulo: LM\&X, 2004.

RAICHELIS, Raquel. Esfera Pública e conselhos de assistência social. São Paulo: Cortez, 1998.

RESENDE, Fernando; TAFNER, Paulo. Brasil: O Estado de uma nação. Brasília: IPEA, 2005.

RIBEIRO, Ana Clara; GRAZIA, Grazia de. Experiências do orçamento participativo no Brasil: período de 1997 a 2000. Petrópolis: Vozes, 2003.

SANTOS JR., Orlando Alves dos; RIBEIRO, Luiz Cesar Queiroz; AZEVEDO Sergio de. Governança democrática e poder local. Rio de Janeiro: Revan/ Observatório Metrópoles, 2004.

TATAGIBA, Luciana. Os Conselhos gestores e a democratização das políticas públicas no Brasil. In: DAGNINO, Evelina (Org.). Sociedade civil e espaços públicos no Brasil. São Paulo: Paz e Terra, 2002. p. 47-104.

TONELLA, Celene; ALMEIDA, Carla Cecília Rodrigues. Participação Social e Indicadores de Associativismo: um estudo sobre entidades 
credenciadas pelos Conselhos Municipais de Assistência Social. In: Seminário Nacional do NPMS/UFSC Movimentos Sociais, Participação e Democracia, 2, 2007. Florianópolis. Banco de Papers. Florianópolis: Seminário Nacional do NPMS/UFSC, 2007. Disponível em: <http://www.npms.ufsc.br>. Acesso em: 25 mai. 2008.

TONELLA, Celene. Conselhos municipais de políticas públicas na região de Maringá. In: FUKS, Mário; PERISSINOTTO, Renato ; SOUZA, Nelson Rosário (Org.). Democracia e participação: os conselhos gestores no Paraná. Curitiba: Editora UFPR, 2004. p. 181-220.

Poder local e políticas públicas: o papel dos conselhos gestores. Maringá: Eduem, 2006.

VIEIRA, Edvaldo. O que é desobediência civil. São Paulo: Brasiliense, 1984. 